\title{
ZAWODOWE UWARUNKOWANIA ZADOWOLENIA Z PRACY WŚRÓD NAUCZYCIELI
}

\begin{abstract}
Streszczenie: Praca stanowi podstawową formę aktywności człowieka, a zadowolenie odczuwane z jej realizacji staje się źródłem satysfakcji życiowej. Jest to szczególnie ważne w przypadku pracy nauczyciela. Badania pokazują, że im wyższe jest zadowolenie z pracy nauczycieli, tym niższe są wskaźniki wypalenia zawodowego. W artykule przedstawiono zagadnienie dotyczące zawodowych uwarunkowań zadowolenia z pracy nauczycieli - kobiet i mężczyzn na trzech etapach stażu zawodowego: adaptacji zawodowej - od roku do pięciu lat stażu; stabilizacji zawodowej - od sześciu do 20 lat stażu; eksperckim - od 21 do 35 lat stażu. Sprawdzono, czy płeć i staż pracy determinują poziom zadowolenia z pracy i poziom zadowolenia z życia wśród badanych nauczycieli. Pokazano także współzależności między zadowoleniem z pracy a zadowoleniem z życia nauczycieli - kobiet i mężczyzn w wyróżnionych okresach stażu pracy.
\end{abstract}

Słowa kluczowe: zadowolenie z pracy, zadowolenie z życia, wypalenie zawodowe.

\section{Wprowadzenie}

Praca stanowi podstawową formę aktywności człowieka i sytuuje go w odpowiednim kontekście psychologicznym, społecznym, zawodowym i osobistym. Jest ona wartością, celowym działaniem, źródłem zarobku, ale też szansą na realizowanie własnych celów, pragnień czy osobistych marzeń. Dzięki niej człowiek zaspokaja potrzeby biologiczne, społeczne, ekonomiczne oraz psychiczne, m.in. potrzeby sukcesu, przynależności, uznania, szacunku i samorealizacji, jest również włączony w system interakcji społecznych, które kształtują go i wpływają na jakość jego życia $^{1}$. Z pracą kojarzone są kluczowe terminy, takie jak zadowolenie i satysfakcja, do których dopisuje się wspomniane wcześniej pojęcie jakości życia.

${ }^{1}$ Zagadnienia związane z definiowaniem i konceptualizowaniem pojęcia jakości życia podejmują Wnuk i in. (2013). Z przeprowadzonych rozważań wynika, że pojęcie jakości życia jest wielowymiarowe i interdyscyplinarne, niemające jednolitej definicji. W naukach społecznych 
Praca zarobkowa jest ważnym aspektem życia dorosłych, stąd zadowolenie i satysfakcja odczuwane z jej realizacji stają się źródłem satysfakcji życiowej. W artykule podejmuję zagadnienie dotyczące zawodowych uwarunkowań zadowolenia z pracy i życia wśród nauczycieli szkół podstawowych i gimnazjalnych.

\section{Pojęcia satysfakcji i zadowolenia}

Realizacja zawodowa w efekcie winna prowadzić do odczuwania przez jednostkę poczucia zadowolenia i satysfakcji, które są pojęciami bliskoznacznymi, ale różnicowanymi w literaturze przedmiotu. Magdalena Kaczkowska-Serafińska (2011) np. w określeniach obu pojęć uwzględnia czynniki motywujące. W tym ujęciu zadowolenie z pracy oznacza pozytywny stosunek pracowników do zadań, warunków pracy, przełożonych i współpracowników i jest wynikiem oddziaływania czynników zewnętrznych: wynagrodzenia, warunków materialnego środowiska pracy, stosunków międzyludzkich, stylu kierowania. Satysfakcja natomiast stanowi wyższy poziom zadowolenia z pracy i wiąże się z oddziaływaniem czynników zewnętrznych i wewnętrznych: możliwości uczenia się, powierzonej odpowiedzialności, uznania zwierzchników. Zadowolenie jest więc warunkiem niezbędnym do osiągnięcia satysfakcji z pracy. W tym kontekście można przyjąć stanowisko, że satysfakcja jest szerszą kategorią pojęciową i zawiera w sobie aspekt zadowolenia z pracy. Elementem różnicującym zadowolenie i satysfakcję z pracy może być tu czas. Zadowolenie z pracy jest reakcją sytuacyjną, zmienną, zaś satysfakcja z pracy jest wynikiem kilku efektów zadowolenia i „obejmuje najczęściej zadania względnie trwałe i powtarzalne, o większym stopniu złożoności i trudności (Wudarzewski 2013, s. 337).

Satysfakcja z pracy oznacza możliwość realizowania przez jednostkę jej własnych potrzeb, celów, wartości, przekonań (Bartkowiak 2009, s. 119), co stanowi bazę do kształtowania się postawy wobec zadań zawodowych. W konsekwencji prowadzi to do ujęcia terminu „zadowolenie”, który uwzględnia aspekt postawy osoby wobec pracy, wyrażającej się poprzez to, co jednostka odczuwa i myśli na temat swojej pracy (Organ i Near 1985, za: Zalewska 2002, s. 199). Takie rozumienie pojęcia spotykamy u Arthura Briefa, według którego „zadowolenie z pracy jest postawą oznaczającą stan wewnętrzny, ocenę, w jakim stopniu doświadczana praca jest korzystna lub niekorzystna dla osoby, wyrażaną w reakcjach afektywnych i ocenach poznawczych. Aspekt poznawczy zadowolenia z pracy bywa nazywany satysfakcją z pracy, a aspekt emocjonalny - samopoczuciem lub nastrojem w miejscu pracy" (za: Zalewska 2001, s. 200). Satysfakcja pracownicza jest więc określoną postawą wobec pracy rozumianą w aspekcie poznawczym (Borowska-Pietrzak 2014). Dla

podkreśla się charakterystyczne aspekty jakości życia. I tak np. socjolodzy zajmują się jakością życia w kontekście zasad i stylów życia społecznego, psycholodzy - poczucia szczęścia, zadowolenia lub dobrostanu, pedagodzy - wartości, celów i dążeń. 
analiz przeprowadzonych w artykule ważne jest stanowisko Janusza Czapińskiego (1994), z którego wynika, że aspekt poznawczy jest bardziej stabilny; on nadaje doświadczeniom człowieka ogólny ton afektywny, a aspekt emocjonalny jest silnie modyfikowany przez zmiany sytuacyjne.

Z przedstawionych stanowisk wynika potrzeba dalszych badań nad obu zjawiskami - zadowoleniem i satysfakcją z pracy.

Zwraca się uwagę na to, że praca nie jest odizolowana od innych sfer życia i że istnieją współzależności między zadowoleniem z pracy a zachowaniami pracowników (Borowska- Pietrzak 2014, s. 11). W literaturze prezentowane są wyniki badań wskazujące na to, że satysfakcja z pracy może w sposób istotny wpływać na jakość życia (Wołowska 2013).

$\mathrm{W}$ przeprowadzonych analizach występuje także termin dobrostanu. Z perspektywy psychologii humanistycznej satysfakcja jest rozumiana jako dobrostan jednostki związany z faktem zatrudnienia, w którym przeważają nadzieja, spokój, optymizm, i która traktowana jest jako cel sam w sobie (Dobrowolska 2010).

W swoich rozważaniach podejmuję, jak wcześniej napisałam, temat zadowolenia z pracy zawodowej w grupie nauczycieli. Ta grupa zawodowa jest szczególnie poddawana ocenie społecznej, a realizacja siebie w zawodzie nie zawsze jest zbieżna z poczuciem sukcesu, zadowolenia czy satysfakcji. Wyniki licznych badań pokazują, że zadowolenie $\mathrm{z}$ wykonywanych obowiązków zawodowych wpływa korzystnie na efekty pracy, ale też na samopoczucie jednostki i stan jej zdrowia psychicznego (Bańka 2000; Zalewska 2001). Z kolei brak satysfakcji, niezadowolenie obniżają skuteczność pracy i przyczyniają się do szybkiego wypalenia zawodowego (Poraj 2009, s. 274).

\section{Przegląd wybranych badań nad satysfakcją i zadowoleniem z pracy}

W literaturze, zwłaszcza psychologicznej, istnieją różne techniki służące do pomiaru satysfakcji z pracy zawodowej, wśród których najbardziej popularne są kwestionariusze. Ich wykorzystanie pozwoliło na zebranie bogatego materiału badawczego na temat zadowolenia nauczycieli z ich pracy zawodowej, co znajduje wyraz w raporcie pt. Polscy nauczyciele i dyrektorzy na tle międzynarodowym. Główne wyniki badania TALIS 2013 oraz Raporcie o stanie edukacji 2013. Licza się nauczyciele. $\mathrm{Z}$ badań tych wynika, iż nauczyciele edukacji wczesnoszkolnej w zdecydowanej większości są zadowoleni z wyboru zawodu, z wyraźną przewagą zadowolenia $\mathrm{w}$ grupie nauczycieli $\mathrm{w}$ wieku powyżej 50 lat. Zdaniem badanych nauczycieli, praca zawodowa zapewnia im kontakty z innymi osobami ( 96 proc.), ale też daje poczucie osobistego rozwoju ( 86 proc.). Podobny poziom zadowolenia wykazują nauczyciele gimnazjum (94 proc.), przy czym mężczyźni w zawodzie nauczyciela odczuwają nieco niższą satysfakcję niż kobiety-nauczycielki.

Analizując związek między zadowoleniem i niezadowoleniem z pracy, należy odwołać się do teorii Fridericka Herzberga. Twierdzi on, że zadowolenie 
i niezadowolenie z pracy powodują różne czynniki występujące w środowisku zawodowym. Czynniki, które powodują zadowolenie, Herzberg nazwał motywatorami, te natomiast, które, wywołują niezadowolenie z pracy - czynnikami higieny. Do motywatorów zalicza się: dokonania, uznanie, treść pracy, odpowiedzialność, awans, możliwości rozwoju, a do czynników higieny: relacje interpersonalne, warunki pracy, organizację, kierownictwo, wynagrodzenie (za: Springer 2011; Sowińska 2014). Odpowiedni poziom motywatorów przyczynia się do rozwinięcia potrzeb wyższych i sprzyja zadowoleniu z pracy, ich niski poziom zaś może przyczyniać się do niezadowolenia z pracy. Z kolei odpowiedni poziom warunków higieny zaspokaja potrzeby niższe, eliminuje niezadowolenie, choć nie przyczynia się do osiągnięcia zadowolenia z pracy. Rozwinięciem teorii Herzberga jest trójczynnikowa koncepcja czynników motywacji, w której wymienia się obok motywatorów i czynników higieny także czynniki zwane demotywatorami; ich pojawienie się wywołuje niezadowolenie. Waldemar Stelmach (2005), na podstawie przeprowadzonych badań empirycznych, wskazał takie przyczyny demotywacji: niejasność przepisów, wywieranie presji na pracowników do wykonywania prac nie w pełni zgodnych z przepisami i etyką zawodową, pozoranctwo, nierówny podział obowiązków, brak kursów dokształcających, presję i obawę przed utratą pracy. Leszek Kozioł (2011) wymienia następujące demotywatory: pracę przekraczającą możliwości psychofizyczne pracownika lub jego kwalifikacje, zawieranie umów na krótkie okresy, negatywne zachowania konieczne do osiągnięcia celów organizacji, niemożność zmiany stanu faktycznego (bezsilność), mobbing, stres spowodowany amoralnym zachowaniem się przełożonych czy współpracowników. W badaniu nad motywacją do pracy należy uwzględniać wszystkie czynniki: motywatory, czynniki higieny, demotywatory. Wektory ich oddziaływania są rozbieżne, ale mogą one występować równocześnie w środowisku pracy (Kozioł 2011; Sowińska 2014).

Płeć od dawna wzbudza zainteresowanie jako czynnik, który może determinować zadowolenie $\mathrm{z}$ pracy. Zgodnie z panującym przekonaniem praca ma większą wagę dla mężczyzn niż dla kobiet, a jej posiadanie jest ważniejsze dla kobiet niż dla mężczyzn (Czarnota-Bojarska 2004). Stawia się hipotezy, że ogólne funkcjonowanie zawodowe i zadowolenie z pracy u mężczyzn jest powiązane $\mathrm{z}$ innymi czynnikami niż u kobiet (Spector 1997, za: Zalewska 2009). Mężczyźni łączą zadowolenie z pracy z czynnikami związanymi z samą pracą - motywatorami takimi jak treść pracy, możliwości rozwoju. Praca jest dla nich wartością samą w sobie. Kobiety traktują pracę bardziej instrumentalnie. Dla ich zadowolenia z pracy ważne są czynniki higieny - relacje z pracownikami, płaca (Czarnota-Bojarska, Łada 2004; Zalewska 2009). Z badań wynika, że staż pracy wiąże się także z różnymi uwarunkowaniami płynącego z niej zadowolenia (Czarnota-Bojarska, Łada 2004). 


\section{Założenia badań własnych}

Cele badań i problematyka badawcza

Wcześniejsze wyniki analiz wskazują na grupy czynników, które w znaczący sposób wpływają na poczucie zadowolenia lub niezadowolenia z pracy, a występują w dwóch obszarach: pola zawodowego i pozazawodowego (Poraj 2009).

Głównym celem przeprowadzonych analiz było: a) ustalenie współzależności między zmienną zależną - zadowoleniem z pracy a zmiennymi niezależnymi czynnikami funkcjonowania zawodowego nauczycieli (kobiet i mężczyzn o różnym stażu pracy, tzw. korelacje); b) ustalenie strukturalnych zależności między zadowoleniem z pracy a wydzielonymi zmiennymi funkcjonowania zawodowego, co dotyczyło wyników badań nauczycieli - kobiet i mężczyzn o różnym stażu pracy (krokowa analiza regresji). Porównano także poziomy zadowolenia z pracy nauczycieli i nauczycielek oraz wszystkich nauczycieli o różnym stażu pracy. W końcowej części ustalono współzależności między zadowoleniem z pracy (zmienna niezależna) a zadowoleniem z życia (zmienna zależna) w grupach nauczycieli i nauczycielek o różnym stażu pracy.

W artykule podjęto próbę poszukiwania odpowiedzi na następujące pytania badawcze: 1) Jakie są zawodowe uwarunkowania zadowolenia z pracy nauczycieli-kobiet i nauczycieli-mężczyzn o różnym stażu pracy? i 2) Jak płeć i staż pracy determinują poziom zadowolenia z pracy i zadowolenia z życia nauczycieli?

Badania mają charakter eksploracyjny, nie formułowano więc hipotez.

\section{Zastosowane metody badawcze}

Dobór metod badawczych podyktowany był problematyką badawczą i celami badania. Zastosowano:

1. Kwestionariusz Obciążeń Zawodowych Pedagoga (KOZP) J. Pyżalskiego i P. Plichty (2007) - przeznaczony jest do identyfikacji stresorów związanych z wykonywaniem zawodu pedagoga. KOZP tworzą trzy skale: sytuacje konfliktowe (SK) - obciążenia wynikające z konfliktów z innymi osobami w sytuacji zawodowej; brak sensu pracy (BSP) - obciążenia wynikające $\mathrm{z}$ braku efektów pracy lub długiego oczekiwania na nie; obciążenia organizacyjne (OO) na poziomie makro- i danej placówki.

2. Kwestionariusz MBI Maslach Burnout Inventory - skonstruowany został do celów diagnozy wypalenia zawodowego (Maslach, Jackson, Leiter 1996). MBI bada trzy dymensje wypalenia zawodowego: emocjonalne wyczerpanie, depersonalizację i poczucie osiągnięć.

3. Kwestionariusz Obszary Życia Zawodowego (AWS) C. Maslach i M. Leitera w polskiej adaptacji J. Terelaka i A. Izwantowskiej (2009). AWS pozwala na 
oszacowanie funkcjonowania pracownika w środowisku pracy oraz niezgodności pomiędzy wymaganiami organizacji i potrzebami, aspiracjami i możliwościami pracowników. Narzędzie obejmuje sześć skal: obciążenie pracą, kontrola zachowań w pracy, satysfakcja z nagród, wsparcie ze strony współpracowników (społeczność), poczucie sprawiedliwości, wartości.

4. Kwestionariusz Poczucia Misji Społecznej w zawodzie (PMS), autorstwa B. Bajcar, Borkowskiej, A. Czerw i A. Gąsiorowskiej (2011). Narzędzie powstało w oparciu o definicję misji zawodowej, która uwzględnia cztery jej obszary: poczucie dużej użyteczności społecznej, zaangażowanie w wykonywanie swojej pracy, oczekiwanie społecznego uznania, wykonywanie pracy niezależnie od wynagrodzenia.

5. Kwestionariusz Orientacji na Wartości Zawodowe (OWZ) K. H. Seiferta i C. Bergmanna, w polskim opracowaniu A. Zalewskiej (2000). Źródłem narzędzia jest koncepcja wartości zawodowych Supera. Definiuje on wartości zawodowe jako cele, które ludzie uważają za ważne i które chcą osiągnąć w pracy zawodowej. OWZ pozwala na oszacowanie 16 wartości zawodowych: altruizmu, kreatywności, stymulacji intelektualnej, autonomii, zmienności, osiągnięć, prestiżu, kierowania, dochodu, bezpieczeństwa, stosunków z kolegami, stosunków z przełożonymi, warunków pracy, wartości estetycznych, awansu, orientacji na czas wolny obejmującej także negatywną postawę wobec pracy.

6. Arkusz Opisu Pracy (AOP) O. Neubergera i M. Allerbecka, w polskim opracowaniu A. Zalewskiej (2001) - umożliwia pomiar satysfakcji z pracy z uwzględnieniem siedmiu składników pracy: kolegów, przełożonych, treści pracy, warunków pracy, organizacji i kierownictwa, rozwoju, wynagrodzenia. Równocześnie AOP pozwala na oszacowanie ogólnej satysfakcji z pracy oraz dokonania pomiaru ogólnej satysfakcji z życia.

\section{Grupa badawcza}

Grupę badawczą stanowi 308, w tym 257 kobiet i 51 mężczyzn, czynnych zawodowo nauczycieli z losowo dobranych szkół z terenu województwa świętokrzyskiego, którzy wyrazili zgodę na udział w badaniu². Staż pracy badanych mieścił się w przedziale od roku do 35 lat. Dla potrzeb dokonania szczegółowych analiz zgromadzonego materiału empirycznego przyjęto, na podstawie znanych psychologicznych i pedagogicznych koncepcji rozwoju zawodowego (por. Poraj 2009), umownie trzy etapy stażu: od roku do pięciu lat - okres wstępnej adaptacji do zawodu: 31 nauczycieli; od sześciu do 20 lat - etap profesjonalnej stabilizacji zawodowej: 117 nauczycieli; od 21 do 35 lat - etap ekspercki; nauczyciel jest doświadczonym i skutecznym specjalistą: 160 nauczycieli. Ten podział jest umowny, przyjęty został dla potrzeb analizy ilościowej uzyskanych wyników.

${ }^{2}$ Badania te dotyczą problematyki wypalenia zawodowego u nauczycieli. Uzyskane wyniki pozwoliły także na analizę tytułowej kwestii. 


\section{Wyniki badań własnych}

Uzyskany w badaniach materiał empiryczny poddano analizom statystycznym przy wykorzystaniu pakietu SPSS. Dla określenia współzależności i siły związku pomiędzy zmiennymi wykorzystano współczynniki Spearmana. W celu ustalenia powiązań strukturalnych między zmiennymi zastosowano analizę liniowej regresji krokowej. Było to możliwe, ponieważ zaobserwowane reszty mają rozkład normalny. W celu wnioskowania o istotności różnic między wynikami porównywanych grup wykorzystano test U Mana Whitneya oraz test Kruskala-Wallisa.

\section{Determinanty zadowolenia z pracy}

Wyniki charakteryzujące korelacje pomiędzy zadowoleniem z pracy kobiet i mężczyzn (tab.1) o różnym stażu pracy są zróżnicowane. Przedstawione wyniki badań potwierdzają, że mężczyźni traktują pracę bardziej zadaniowo, uwarunkowania ich zadowolenia z pracy są mniej liczne niż u kobiet.

Stwierdzono, że dla zadowolenia z pracy wszystkich badanych nauczycielek ważne są następujące czynniki: dopasowanie w obszarach nagród, sprawiedliwość, wartości, pozytywne oceny przełożonego, treści pracy, warunki pracy, organizacja i kierownictwo.

W wyniku obserwacji danych przedstawionych w tab. 1 wyodrębnione zostały specyficzne korelacje dla osiągnięcia zadowolenia z pracy: a) w grupie mężczyzn: w okresie adaptacji zawodowej negatywna orientacja na estetykę; w okresie stabilizacji zawodowej - ujemna z poczuciem braku osiągnięć; b) w grupie kobiet: w okresie adaptacji zawodowej - dodatnia $z$ orientacją na altruizm i estetykę; w okresie stabilizacji zawodowej - ujemna z orientacją na zmienność; w okresach stabilizacji zawodowej i eksperckim - ujemna z emocjonalnym wyczerpaniem, dodatnia z wagą stosunków z kolegami, również dodatnia z ocenami rozwoju, wynagrodzenia, pewności miejsca pracy; w okresie eksperckim - ujemna z obciążeniami organizacyjnymi, dodatnia z wagami prestiżu, bezpieczeństwa, dochodu, awansu, osiągnięć, zmienności, dobrych warunków miejsca pracy i jego przyjemnej atmosfery, również dodatnia z orientacją na autonomiczny styl życia.

Tylko w grupach nauczycielek i nauczycieli pracujących od sześciu do 20 lat w zawodzie korelują ze sobą ujemnie zadowolenie z pracy z depersonalizacją. Wynik ten może wskazywać na to, że w okresie adaptacji zawodowej zadowolenie z pracy nauczycieli wzrasta przy zmniejszającym się dystansie wobec innych ludzi i odchodzeniu od uprzedmiotowienia relacji z nimi.

Specyficznym pozytywnym korelatem zadowolenia z pracy nauczycieli i nauczycielek pracujących powyżej 21 lat okazała się orientacja na wartości estetyczno-wolnościowe. Dobrostan zawodowy kobiet rośnie, gdy wzrasta ich orientacja na dowolne urządzanie sobie życia w czasie wolnym, w przypadku natomiast dobrostanu zawodowego mężczyzn istotna jest orientacja na działalność, która 
Tabela 1. Zależności między zadowoleniem z pracy nauczycieli i czynnikami pracy

\begin{tabular}{|c|c|c|c|c|c|c|c|}
\hline \multicolumn{2}{|r|}{ STAŻ PRACY } & $\begin{array}{l}\text { STAZ PRACY } \\
\text { DO } 5 \text { LAT }\end{array}$ & $\begin{array}{l}\text { STAZ PRACY } \\
\text { OD 6-20 LAT }\end{array}$ & $\begin{array}{l}\text { STAZ PRACY } \\
\text { OD } 21 \text { LAT }\end{array}$ & $\begin{array}{c}\text { STAZ PRACY } \\
\text { DO S LAT }\end{array}$ & $\begin{array}{l}\text { STAZ PRACY } \\
\text { OD 6-20 LAT }\end{array}$ & $\begin{array}{l}\text { STAZ PRACY } \\
\text { OD } 21 \text { LAT }\end{array}$ \\
\hline & CZYNNIKI PRACY & \multicolumn{3}{|c|}{ MEZZCZYŹNI } & \multicolumn{3}{|c|}{ КОВІЕTY } \\
\hline \multirow{3}{*}{ KOZP } & SYTUACE KONFLIKTOWE & $\cdot 0,152$ & $\cdot 0,304$ & 0,178 & 0,214 & $\cdot 0,033$ & $\cdot 0,005$ \\
\hline & OBCLĄŻENLA ORGANIZACYJNE & 0,626 & $.0,117$ & 0,17 & $.0,263$ & $\cdot 0,168$ &,$- 327^{* *}$ \\
\hline & BRAK SENSU PRACY & 0,503 & $\cdot 0,257$ & 0,132 & $\cdot 0,241$ & $\cdot 0,067$ & $\cdot 0,018$ \\
\hline \multirow{3}{*}{ MEI } & EMOCONALNE WYCZERPANIE & $\cdot 0,579$ & $\cdot 0,377$ & 0,099 & $\cdot 0,057$ & .504 & $-179^{\circ}$ \\
\hline & DEPERSONALIZACJA & 0,101 &., $565^{\circ *}$ & 0,142 & $-0,32$ &., $365^{* *}$ & $\cdot 0,074$ \\
\hline & BRAK POCZUCIA OSLĄGNIĘC் & $\cdot 0,603$ & $-490^{\circ}$ & $\cdot 0,006$ & $\cdot 0,388$ & $\cdot 0,128$ & $\cdot 0,143$ \\
\hline \multirow{6}{*}{ AWS } & OBCLAQŻENIE PRACA & $.0,299$ & 0,244 & 0 & 0,2 & $\cdot 0,008$ & 0,097 \\
\hline & POCZUCIE KONTROLI & $-0,02$ & 706 & 0,079 & $517^{\circ *}$ & 0,132 & 0,135 \\
\hline & NAGRODY & 0 & $586^{4+}$ & 0,281 & $.419^{\circ}$ & $238^{\circ}$ & ,243"0 \\
\hline & SPOLECZNOŚĊ & $.0,237$ & 596 & $\cdot 0,209$ & $565^{*-}$ & 0,175 & 249 \\
\hline & POCZUCIE SPRAWIEDLIWOṠCI & $.0,292$ & 0,344 & 0,092 & $501^{\circ}$ & $258^{\circ}$ & $281=$ \\
\hline & WARTOŚCI & $.0,279$ & $446^{\circ}$ & 0,29 & $638^{*}$ & 388 & $269=$ \\
\hline \multirow{4}{*}{ PM5 } & SPOLECZNA UŻYTECZNOŚĊ & 0,094 & $\cdot 0,229$ & $\cdot 0,077$ & $.0,289$ & $\cdot 0,128$ & $\cdot 0,082$ \\
\hline & SPOLECZNE UZNANIE & $\cdot 0,511$ & $.0,408$ & 0,013 & $.0,015$ & $\cdot 0,139$ & $.0,044$ \\
\hline & WAŻNOŚĊ WYNA GRODZENIA & $-0,48$ & $\cdot 0,283$ & 0,088 & $.0,146$ & $.0,03$ & $\cdot 0,125$ \\
\hline & SILNE ZAA NGAZZOWANIE & $\cdot 0,325$ & $\cdot 0,395$ & $\cdot 0,029$ & $\cdot 0,061$ & $\cdot 0,189$ & $\cdot 0,031$ \\
\hline \multirow{18}{*}{ owz } & PRESTIZ & $\cdot 0,692$ & 0,09 & 0,135 & 0,142 & 0,122 &, $268^{* 0}$ \\
\hline & KIEROWNICTWO & $\cdot 0,402$ & $\cdot 0,337$ & 0,069 & $\cdot 0,128$ & 0,069 & 0,063 \\
\hline & DOCHÓD & $\cdot 0,132$ & $\cdot 0,1$ & $\cdot 0,049$ & $\cdot 0,399$ & $\cdot 0,081$ & $168^{\circ}$ \\
\hline & BEZPIECZEṄSTWO & $.0,658$ & 0,265 & 0,099 & 0,332 & 0,2 & ,233*• \\
\hline & AWAN5 & $\cdot 0,011$ & $\cdot 0,094$ & $\cdot 0,104$ & 0,171 & 0,032 &, 244 \\
\hline & KREATYWNOṠC & $\cdot 0,568$ & $\cdot 0,104$ & 0,145 & 0,325 & 0,096 & 0,042 \\
\hline & STYMULACJA INTELEKTUALNA & 0,124 & 0,167 & $\cdot 0,084$ & 0,225 & $\cdot 0,051$ & 0,166 \\
\hline & AUTONOMIA & 0,052 & $\cdot 0,205$ & 0,09 & 0,037 & $\cdot 0,126$ & 0,005 \\
\hline & UROZMAICONA DZIALALNOŚĊ & $\cdot 0,447$ & $\cdot 0,138$ & 0,11 & 0,273 & $-247^{\circ}$ &, $213^{\circ}$ \\
\hline & STOSUNKI Z KOLEGAMI & $\cdot 0,363$ & 0,372 & 0,139 & 0,395 & $208^{\circ}$ &, $177^{\circ}$ \\
\hline & STOSUNKI Z PRZEK OŻONYMI & 0,042 & 0,216 & 0,255 & 0,366 & 0,148 & 0,14 \\
\hline & DOBRE WARUNKI & $.0,422$ & 0,102 & 0,097 & $\cdot 0,024$ & 0,142 & ,281"• \\
\hline & PRZYJEMNA ATMOSFERA & $\cdot 0,422$ & $-0,14$ & 0,007 & 0,282 & 0,146 &, $215^{\circ}$ \\
\hline & ALTRUIZM & $\cdot 0,167$ & 0,128 & 0,349 & $489^{\circ}$ & 0,053 & $.0,023$ \\
\hline & ESTETYKA & $-827^{\circ}$ & $\cdot 0,255$ & $\cdot 0,082$ &, $470^{\circ}$ & 0,074 & 0,126 \\
\hline & AUTONOMICZNY STYL ŻYCIA & 0,176 & 0,063 & 0,232 & 0,228 & $\cdot 0,166$ & $199^{\circ}$ \\
\hline & DUZZO CZASU WOLNEGO NA HOBBY & $\cdot 0,473$ & $\cdot 0,33$ & $486^{\circ}$ & $\cdot 0,169$ & $\cdot 0,154$ & $\cdot 0,011$ \\
\hline & OSIĄGNIĘCLA & $\cdot 0,605$ & 0,31 & 0,269 & 0,291 & 0,051 & ,323*- \\
\hline \multirow{8}{*}{ AOP } & KOLEDZY & 0,402 & 0,293 & 0,123 & 0,342 & 0,026 & $2211^{*}$ \\
\hline & PRZELOŻONY & $\cdot 0,579$ & 0,334 & 0,268 & $647^{*}$ & $239^{\circ}$ & ,350"• \\
\hline & WYKONYW ANA PRACA & 0,07 & $498^{\circ}$ & 0,427 & $703^{1 *}$ & $229^{\circ}$ & $446^{*-}$ \\
\hline & WARUNKI PRACY & $-0,01$ & 0,406 & 0,34 &, $412^{\circ}$ & $347^{*}$ & ,342*- \\
\hline & ORGANIZACIA I KIEROWNICTWO & 0,02 & 0,359 & 0,396 & $574^{* *}$ & $479^{* *}$ & 385 \\
\hline & ROzWȮJ & $\cdot 0,112$ & 0,322 & $.444^{\circ}$ & 0,09 & $380^{\circ}$ & ,369"- \\
\hline & WYNAGRODZENIE & 0,724 & $418^{\circ}$ & 0,074 & 0,156 & $509^{*-}$ & ,303"* \\
\hline & ZAPEWNIONE MIEJSCE PRACY & $\cdot 0,584$ & 0,1 & $.5911^{\circ}$ & 0,269 & $2788^{*}$ & $412^{*-}$ \\
\hline
\end{tabular}

Źródło: opracowanie własne. 
pozostawia dużo wolnego czasu na zajmowanie się sprawami prywatnymi i hobby. Taka orientacja wyraża z jednej strony negatywną postawę wobec pracy, z drugiej zaś każe zwrócić uwagę na zjawisko karier paralelnych wyrażających się w modelu zatrudnienia „1+” (Kędzierska 2012).

W celu ustalenia powiązań strukturalnych między zadowoleniem z pracy nauczycieli i nauczycielek o różnym stażu zawodowym a badanymi zmiennymi zawodowymi zastosowano analizę liniowej regresji krokowej (tab.2).

Uzyskane dane wskazują na różne determinanty zadowolenia z pracy u mężczyzn i kobiet o różnym stażu pracy. W przypadku mężczyzn pracujących do pięciu lat nie stwierdzono zależności między zadowoleniem z pracy a jakimkolwiek $z$ analizowanych czynników pracy. Przyjęte zmienne funkcjonowania zawodowego wyjaśniają $\mathrm{w} 49$ proc. zadowolenie z pracy u mężczyzn w okresie stabilizacji zawodowej pracujących od sześciu do 20 lat w zawodzie nauczyciela. Istotny, pozytywnie stymulujący wpływ, mają tutaj dwie zmienne: dopasowanie w obszarze kontroli oraz ocena treści wykonywanej pracy. Poziom zadowolenia z pracy u mężczyzn pracujących ponad 21 lat, w okresie eksperckim, zmienne zawodowe wyjaśniają w 66 proc. Istotność parametrów równań regresyjnych dotyczy pozytywnie ocen pewności miejsca pracy i treści wykonywanej pracy, także orientacji na kierownictwo, ujemnie natomiast orientacji na awans i dochód.

Z zestawienia wynika, że czynniki zawodowe wyjaśniają w 89 proc. poziom zadowolenia $\mathrm{z}$ pracy w grupie nauczycielek będących w okresie adaptacji zawodowej. Równanie regresyjne obejmuje pięć czynników. Istotny, znacząco pozytywnie stymulujący wpływ, ma ocena treści wykonywanej pracy. Taki sam kierunek łączy się z orientacją na estetykę. Wartość predyktywną, ale negatywną, mają tu także orientacja na dochód oraz wyraźnie ocena przełożonego i depersonalizacja.

Poziom zadowolenia z pracy u kobiet o stażu pracy od sześciu do 20 lat wyjaśniany jest przez przyjęte czynniki zawodowe w 35 proc. Pozytywny predyktywny udział mają tu satysfakcja z wynagrodzenia i orientacja na stosunki z przełożonym. Negatywną wartość predyktywną przynosi depersonalizacja. Destymulującym predyktorem jest też czynnik związany z poczuciem zawodowej misji społecznej, a mianowicie poczucie społecznej użyteczności.

Udział przyjętych zmiennych w wyjaśnianiu zadowolenia z pracy u nauczycielek, które pracują najdłużej, powyżej 21 lat, wynosi 32 proc. W równaniu regresyjnym istotne okazały się takie zmienne, jak: satysfakcja $\mathrm{z}$ treści wykonywanej pracy, pewność miejsca pracy, dopasowanie w obszarze społeczności. Przeciwny zaś jest czynnik związany z poczuciem zawodowej misji społecznej - oczekiwanie społecznego uznania dla wykonywanego zawodu. 
Tabela 2. Udział zmiennych niezależnych (czynników pracy) w wyjaśnianiu zmiennej zależnej (zadowolenia z pracy nauczycieli)

\begin{tabular}{|c|c|c|c|c|}
\hline \multicolumn{5}{|c|}{ MĘŻCZYŹNI } \\
\hline $\begin{array}{l}\text { MĘŻCZYŹNI- } \\
\text { STAŻ PRACY } \\
\text { DO } 5 \text { LAT }\end{array}$ & \multicolumn{4}{|c|}{ W równaniu regresji nie ma zmiennych } \\
\hline $\begin{array}{l}\text { MĘŻCZYŹNI- } \\
\text { STAŻ PRACY } \\
\text { OD 6-20 lat }\end{array}$ & \multicolumn{4}{|c|}{$\begin{array}{c}\text { STREFY PRACY I JEJ ZNACZENIE - PRACA - stopień } \\
\text { zadowolenia, skorygowane R-kwadrat=0,49, F=11,67, } \\
\text { p<0,001 }\end{array}$} \\
\hline Predyktory & $B$ & Beta & $t$ & $p$ \\
\hline $\begin{array}{l}\text { AWS- } \\
\text { POCZUCIE } \\
\text { KONTROLI }\end{array}$ & 0,16 & 0,44 & 2,6 & 0,02 \\
\hline $\begin{array}{l}\text { AOP- } \\
\text { WYYKONYW } \\
\text { ANA PRACA }\end{array}$ & 0,1 & 0,38 & 2,5 & 0,02 \\
\hline $\begin{array}{l}\text { MĘŻCZYŹNI- } \\
\text { STAŻ PRACY } \\
\text { OD } 21 \text { lat }\end{array}$ & \multicolumn{4}{|c|}{$\begin{array}{l}\text { STREFY PRACY I JEJ ZNACZENIE - PRACA - stopień } \\
\text { zadowolenia, skorygowane R-kwadrat }=0,66, F=8,777, \\
\qquad<<0,001\end{array}$} \\
\hline Predyktory & $B$ & Beta & $t$ & $p$ \\
\hline $\begin{array}{l}\text { OWS- } \\
\text { ZAPEWNION } \\
\text { E MIEJSCE } \\
\text { PRACY }\end{array}$ & 0,4 & 0,53 & 3,62 & 0,03 \\
\hline $\begin{array}{l}\text { OWS- } \\
\text { DOCHÓD }\end{array}$ & $-0,14$ & $-0,48$ & $-2,32$ & 0,03 \\
\hline $\begin{array}{l}\text { AOP- } \\
\text { WYKONYWA } \\
\text { NA PRACA }\end{array}$ & 0,12 & 0,65 & 4,03 & 0,001 \\
\hline $\begin{array}{l}\text { OWZ- } \\
\text { KIEROWNICT } \\
\text { WO }\end{array}$ & 0,21 & 0,6 & 3,27 & 0,005 \\
\hline $\begin{array}{l}\text { OWZ- } \\
\text { AWANS }\end{array}$ & $-0,18$ & $-0,5$ & $-2,2$ & 0,04 \\
\hline
\end{tabular}

\begin{tabular}{|c|c|c|c|c|}
\hline \multicolumn{5}{|c|}{ KOBIETY } \\
\hline $\begin{array}{l}\text { KOBIETY - } \\
\text { STAŻ PRACY }\end{array}$ & \multicolumn{4}{|c|}{$\begin{array}{c}\text { STREFY PRACY I JEJ ZNACZENIE - PRACA - stopień } \\
\text { zadowolenia, skorygowane R-kwadrat=0,89, F=39,67, } \\
\qquad<0,001\end{array}$} \\
\hline Predyktory & B & Beta & $t$ & $p$ \\
\hline $\begin{array}{l}\text { AOP- } \\
\text { WYKONYWAN } \\
\text { A PRACA }\end{array}$ & 0,22 & 0,76 & 6,89 & $<0,001$ \\
\hline $\begin{array}{l}\text { OWZ- } \\
\text { ESTETYKA }\end{array}$ & 0,23 & 0,52 & 6,74 & $p<0,001$ \\
\hline OWZ-DOCHÓD & $-0,25$ & $-0,57$ & $-6,83$ & $p<0,001$ \\
\hline $\begin{array}{l}\text { MBI- } \\
\text { DEPERSONALI } \\
\text { ZACJA }\end{array}$ & $-0,17$ & $-0,31$ & $-4,56$ & $p<0,001$ \\
\hline $\begin{array}{l}\text { AOP- } \\
\text { PRZEŁOŻONY }\end{array}$ & $-0,1$ & $-0,33$ & $-2,78$ & 0,01 \\
\hline $\begin{array}{l}\text { KOBIETY - } \\
\text { STAŻ PRACY } \\
\text { OD } 6 \text { DO } 20 \\
\text { LAT }\end{array}$ & \multicolumn{4}{|c|}{$\begin{array}{l}\text { STREFY PRACY I JEJ ZNACZENIE - PRACA - stopień } \\
\text { zadowolenia, skorygowane R-kwadrat=0,35, F=13,36, } \\
\text { p<0,001 }\end{array}$} \\
\hline Predyktory & $B$ & Beta & $t$ & $p$ \\
\hline $\begin{array}{l}\text { AOP- } \\
\text { WYNAGRODZE } \\
\text { NIE }\end{array}$ & 0,09 & 0,37 & 4,38 & $<0,001$ \\
\hline $\begin{array}{l}\text { MBI- } \\
\text { DEPERSONALI } \\
\text { ZACJA }\end{array}$ & $-0,12$ & $-0,31$ & $-3,61$ & 0,001 \\
\hline $\begin{array}{l}\text { OWZ- } \\
\text { STOSUNKIZ } \\
\text { PRZEłOŻONY } \\
\text { MI }\end{array}$ & 0,18 & 0,27 & 3,23 & 0,002 \\
\hline $\begin{array}{l}\text { PMS- } \\
\text { SPOŁECZNA } \\
\text { UŻYTECZNOŚĆ }\end{array}$ & $-0,15$ & $-0,19$ & $-2,25$ & 0,03 \\
\hline $\begin{array}{l}\text { KOBIETY - } \\
\text { STAŻ PRACY } \\
\text { OD } 21 \text { LAT }\end{array}$ & \multicolumn{4}{|c|}{$\begin{array}{l}\text { STREFY PRACY I JEJ ZNACZENIE - PRACA - stopień } \\
\text { zadowolenia, skorygowane R-kwadrat=0,32, F=17,26, } \\
\text { p<0,001 }\end{array}$} \\
\hline Predyktory & B & Beta & $t$ & $p$ \\
\hline \begin{tabular}{l||} 
AOP- \\
WYKONYWAN \\
A PRACA
\end{tabular} & 0,08 & 0,38 & 4,95 & $<0,001$ \\
\hline $\begin{array}{l}\text { OWZ- } \\
\text { ZAPEWNIONE } \\
\text { MIESSCE } \\
\text { PRACY } \\
\end{array}$ & 0,18 & 0,23 & 3,04 & 0,003 \\
\hline $\begin{array}{l}\text { AWS- } \\
\text { SPOŁECZNOŚĆ }\end{array}$ & 0,05 & 0,2 & 2,71 & 0,008 \\
\hline $\begin{array}{l}\text { PMS- } \\
\text { WAŻNOŚĆ } \\
\text { WYNAGRODZE } \\
\text { NIA }\end{array}$ & $-0,11$ & $-0,18$ & $-2,44$ & 0,02 \\
\hline
\end{tabular}

Źródło: opracowanie własne.

Wyniki przeprowadzonych analiz sugerują, że poziom zadowolenia z pracy u badanych nauczycieli-kobiet i nauczycieli-mężczyzn o różnym stażu pracy 
determinowany jest istotnie, chociaż w sposób ograniczony, przez różne cechy funkcjonowania zawodowego.

\section{Płeć i staż pracy a zadowolenie z pracy i z życia}

Z przeprowadzonych testem U Manna Whitney’a analiz wynika, że badani nauczyciele nie różnią się $\mathrm{w}$ zależności od płci $\mathrm{w}$ ocenie zadowolenia $\mathrm{z}$ pracy $(\mathrm{p}=$ 0.945) i z życia $(\mathrm{p}=0.544)$ (tab.3). Takie wnioski wypływają też z badań, które przeprowadziła Poraj (2009). Statystyki obliczone dla testu Kruskala-Wallisa pokazały, że nie różnią się także w ocenie zadowolenia $\mathrm{z}$ pracy ze względu na staż pracy $(\mathrm{p}=0.073)($ tab.4). Stwierdzono natomiast istotne różnice w zadowoleniu z życia $(\mathrm{p}=0.048)$. Najbardziej usatysfakcjonowani w tym względzie są nauczyciele pracujący najkrócej - do pięciu lat, najmniej - nauczyciele pracujący od sześciu do 20 lat.

Tabela 3. Poziom zadowolenia z pracy i z życia a płeć nauczycieli

\begin{tabular}{|c|l|c|c|}
\hline \multicolumn{2}{|c|}{ Statystyka } & $\begin{array}{c}\text { Poziom } \\
\text { zadowolenia } \\
\text { zpracy }\end{array}$ & $\begin{array}{c}\text { Poziom } \\
\text { zadowolenia } \\
\text { zżycia }\end{array}$ \\
\hline Mężczyżni & Średnia & 5,1765 & 5,2549 \\
\cline { 2 - 4 } N=51 & Mediana & 5 & 5 \\
\cline { 2 - 4 } & Odchylenie standardowe & 1,16114 & 0,91309 \\
\hline Kobiety & Średnia & 5,1984 & 5,1518 \\
\cline { 2 - 4 } N=257 & Mediana & 5 & 5 \\
\hline \multirow{2}{*}{ Ogółem } & Odchylenie standardowe & 1,03622 & 0,9335 \\
\hline \multirow{2}{*}{ N=308 } & Śrnia & 5,1948 & 5,1688 \\
\cline { 2 - 4 } & Mediana & 5 & 5 \\
\cline { 2 - 4 } & Odchylenie standardowe & 1,05595 & 0,92947 \\
\hline
\end{tabular}

Źródło: opracowanie własne. 
Tabela 4. Poziom zadowolenia z pracy i z życia a staż pracy nauczycieli

\begin{tabular}{|c|l|c|c|}
\hline \multicolumn{2}{|c|}{ Staż pracy } & $\begin{array}{c}\text { Poziom } \\
\text { zadowolenia } \\
\text { z pracy }\end{array}$ & $\begin{array}{c}\text { Poziom } \\
\text { zadowolenia } \\
\text { ż̇ycia }\end{array}$ \\
\hline do 5 lat & Średnia & 5,3947 & 5,3947 \\
\cline { 2 - 4 } N=31 & Mediana & 5 & 5 \\
\cline { 2 - 4 } & Odchylenie standardowe & 1,40538 & 1,00107 \\
\hline 6 do 20 lat & Średnia & 5 & 5,0254 \\
\hline N=117 & Mediana & 5 & 5 \\
\hline \multirow{2}{*}{ od 21 lat } & Odchylenie standardowe & 1,16941 & 1,01663 \\
\hline N=160 & Mediana & 5,2875 & 5,2313 \\
\hline \multirow{2}{*}{ Ogółem } & Odchylenie standardowe & 0,84219 & 0,85577 \\
\hline N=308 & Mediana & 5,193 & 5,1741 \\
\hline & Odchylenie standardowe & 1,05894 & 0,94184 \\
\hline
\end{tabular}

Źródło: opracowanie własne.

Ostatnim krokiem w dokonywanej analizie wyników przeprowadzonych badań jest pokazanie, za pomocą badania korelacyjnego, zależności między zadowoleniem z pracy a zadowoleniem z życia u badanych nauczycieli. Zależność tę prezentuje poniższa tabela.

Tabela 5. Zależność między zadowoleniem z pracy i zadowoleniem z życia nauczycieli

\begin{tabular}{|c|c|c|}
\hline \multirow{2}{*}{ Pleć } & Staż pracy & $\begin{array}{c}\text { Korelacja Spearmana } \\
\text { zadowoleniaz pracy } \\
\text { i z życia }\end{array}$ \\
\hline Mężczyźni & $1-5$ lat & 0,409 \\
\hline \multirow{2}{*}{$N=51$} & $6-20$ lat &, $728^{*}$ \\
\hline & $21-30$ lat & 0,306 \\
\hline Kobiety & $1-5$ lat &, $763^{*}$ \\
\hline N=257 & $6-20$ lat &, $480^{*}$ \\
\hline & $21-30$ lat &, $361^{*}$ \\
\hline
\end{tabular}

Źródło: opracowanie własne. 
Wyniki charakteryzujące korelacje pomiędzy zadowoleniem z pracy a zadowoleniem z życia pokazują istotne współzależności w grupie mężczyzn będących na etapie zawodowej stabilizacji (od sześciu do 20 lat stażu pracy) i w każdej wyróżnionej ze względu na staż pracy grupie kobiet. Jeżeli przyjąć, że najwyższa korelacja sygnalizuje ważność związku, to zadowolenie z pracy jest najważniejsze dla zadowolenia $\mathrm{z}$ życia $\mathrm{w}$ grupach nauczycielek w okresie adaptacji zawodowej i nauczycieli w okresie stabilizacji zawodowej.

\section{Podsumowanie}

Przeprowadzone badania pozwoliły odpowiedzieć na postawione pytania badawcze. Ponieważ wyczerpujące odpowiedzi znajdują się w tekście artykułu, przedstawiono tutaj najważniejsze płynące z nich wnioski.

Na podstawie przeprowadzonych analiz można stwierdzić, że poziom zadowolenia z pracy u badanych nauczycieli-kobiet i nauczycieli-mężczyzn o różnym stażu pracy determinowany jest istotnie, chociaż w sposób ograniczony, przez różne czynniki pracy.

Przedstawione wyniki badań sugerują, że o zadowoleniu z pracy u badanych nauczycieli decydują w sposób szczególny: w okresie adaptacji zawodowej w grupie kobiet - zadowolenie z treści wykonywanej pracy, wysoka orientacja na estetykę, niska orientacja na dochód, niezadowolenie z przełożonego i brak depersonalizacji; w okresie stabilizacji zawodowej w grupie mężczyzn - dopasowanie w obszarze kontroli i zadowolenie z treści wykonywanej pracy; w grupie kobiet - zadowolenie z wynagrodzenia i wysoka orientacja na stosunki z przełożonym, brak depersonalizacji i brak poczucia społecznej użyteczności zawodowej; w okresie eksperckim w grupie mężczyzn - zadowolenie z treści wykonywanej pracy, pewność miejsca pracy, wysoka orientacja na kierownictwo, niska orientacja na awans i taka sama na dochód; w grupie kobiet - satysfakcja z treści wykonywanej pracy, pewność miejsca pracy, dopasowanie w obszarze społeczności, brak oczekiwania na społeczne uznanie zawodowe.

Należy również zauważyć, że niektóre z ujętych determinant zawodowych są specyficzne dla oceny zadowolenia $\mathrm{z}$ pracy wyróżnionych ze względu na płeć i staż pracy grup nauczycieli. W grupie mężczyzn w okresie pracy od sześciu do 20 lat jest to dopasowanie w obszarze kontroli; od 21 do 35 lat - orientacja na dwie wartości zawodowe: negatywna na awans i pozytywna na kierownictwo. W grupie kobiet $\mathrm{w}$ okresie pracy od roku do pięciu lat są to: pozytywna orientacja na estetykę i negatywna ocena przełożonego; od sześciu do 20 lat - pozytywna orientacja na relacje z przełożonym, zadowolenie $\mathrm{z}$ wynagrodzenia, brak poczucia społecznej użyteczności wykonywanego zawodu; zaś w grupie od 21 do 30 lat - dopasowanie w obszarze społeczności i niska waga wynagrodzenia.

Najbardziej zadowoleni z życia są nauczyciele pracujący od roku do pięciu lat, najmniej - pracujący w tym zawodzie od sześciu do 20 lat. 
Zadowolenie z życia u wszystkich kobiet, na każdym wyróżnionym etapie stażu pracy, wzrasta wraz z zadowoleniem z pracy. W grupie mężczyzn taka współzależność wystąpiła tylko u osób w okresie stabilizacji zawodowej - pracujących od sześciu do 20 lat pracy zawodzie nauczyciela.

Problematyka satysfakcji, zadowolenia z pracy poruszana jest często w kontekście wypalenia zawodowego. Badania pokazują, że im wyższe jest zadowolenie z pracy nauczycieli, tym niższe są wskaźniki wypalenia zawodowego (Palak 2007). Nauczycielstwo należy do zawodów szczególnie narażonych na jego wystąpienie (Sęk 1996; Sekułowicz 2002,2005; Tucholska 2009; Kocór 2010; Pyżalski 2010; Kirenko, Zubrzycka-Maciąg 2011; Mojsa-Kaja i in. 2015), a zawód ten tworzy niekorzystne warunki do wypalania się osób obojga płci (Poraj 2009). Maslach i Leiter $(2010,2011)$ twierdzą, że wypalenie zawodowe należy ujmować w złożonym kontekście uwarunkowań zawodowych i w tym przede wszystkim upatrywać jego źródeł. Zgodnie z paradygmatem przedstawionym przez tych autorów, wypalanie oznacza erozję zaangażowania w pracę. „Zaangażowany pracownik silniej identyfikuje się z pracą, jest bardziej optymistyczny przy podejmowaniu nowych wyzwań: ma lepsze ogólne samopoczucie [...] Praca w zgodzie z własnymi odczuciami zmniejsza koszty emocjonalne i przekłada się na podniesienie jakości życia danej osoby we wszystkich sferach" (Sowińska 2014, s. 52-53).

\section{Bibliografia}

Bajcar B., Borkowska A., Czerw A., Gąsiorowska A. (2011). Satysfakcja z pracy w zawodach z misja społeczną. Psychologiczne uwarunkowania. Gdańsk: GWP.

Bańka A. (200o). Psychologia organizacji. W: Strelau J. (red.). Psychologia. Podręcznik akademicki, t. 3 s. 321-350. Gdańsk: GWP.

Bartkowiak G. (2009). Człowiek w pracy. Od stresu do sukcesu w organizacji. Warszawa: Polskie Wydawnictwo Ekonomiczne.

Borowska-Pietrzak A. (2014). Dezagregacja czynników w modelu poczucia satysfakcji zawodowej. „Nauki o Zarządzaniu”, nr 1 (18), s. 10-22.

Czapiński J. (1994). Psychologia szczęścia. Przegląd badań i zarys teorii cebulowej. Warszawa: Oficyna Wydawnicza „Akademos”, Pracownia Testów Psychologicznych. Polskie Towarzystwo Psychologiczne.

Czarnota-Bojarska J., Łada M. (2004). Ważność różnych aspektów pracy dla kobiet i mężczyzn o różnym jej stażu. „Nowiny Psychologiczne”, 1, s. 5-22.

Czas $i$ warunki pracy w relacjach nauczycieli. Raport tematyczny z badania (2013), Warszawa: IBE, dostępny na: http://entuzjaści.pl/images/stories/publikacje/ibe-raport-czas-i-warunki-pracy-nauczycieli.pdf (otwarty: 30.07.2015).

Dobrowolska M. (2010). Związek satysfakcji z pracy $i$ kosztów psychologicznych pracowników tymczasowo zatrudnionych. W: Kożusznik B. przy współudziale Chrupały-Pniak M. (red.). Zastosowania psychologii w zarządzaniu. Katowice: Wydawnictwo Uniwersytetu Śląskiego. 
Kaczkowska-Serafińska M. (2011). Dlaczego przedsiębiorcy powinni dbać o satysfakcję z pracy swoich pracowników? Satysfakcja z pracy - cz. 1. „Postera”, nr 10 (23), s. 11-25.

Kędzierska H. (2012). Kariery zawodowe nauczycieli. Konteksty-wzorce-pola dyskursu. Toruń: Wydawnictwo Adam Marszałek.

Kirenko J., Zubrzycka-Maciąg T. (2011). Współczesny nauczyciel. Studium wypalenia zawodowego. Lublin: Wydawnictwo UMCS.

Kocór M. (2010). Szkoła i nauczyciel a syndrom wypalenia zawodowego. Rzeszów: „Mitel”.

Kozioł L. (2011). Trychotomia czynników motywacji w pracy. „Zeszyty Naukowe MWSE Tarnów", nr 2 (19), s. 45-54.

Maslach, C., Jackson S., Leiter M. P. (1996). The Maslach Burnout Inventory 3-rd. ed. Palo Alto, CA: Consulting Psychologists Press.

Maslach C., Leiter M. P. (2010). Pokonać wypalenie zawodowe. Sześć strategii poprawienia relacji z praca. Warszawa: Wolters Kluwer Polska.

Maslach C., Leiter M. P. (2011). Prawda o wypaleniu zawodowym. Co robić ze stresem w organizacji? Warszawa: Wydawnictwo Naukowe PWN.

Mojsa-Kaja J., Golonka K., Marek T. (2015). Job burnout and engagement among teachers. Worklife areas and personality traits as predictors of relationships with work. International Journal of Occupational Medicine and Environmental Heaalth (28), dostępny na: http://1.www.ncbi.nlm.nih.gov/pubmed/26159952 (otwarty: 30.07.2015).

Palak Z. (2007). Zespół wypalenia zawodowego w pracy nauczycieli szkół specjalnych i ogólnodostępnych, W: Bartkowicz Z., Kowaluk M., Samujło M. (red.). Nauczyciel kompetentny. Teraźniejszość i przyszłość. Lublin: Wydawnictwo UMCS.

Polscy nauczyciele i dyrektorzy na tle międzynarodowym. Główne wyniki badania TALIS 2013, dostępny na: http://entuzjasci.pl/images/stories/publikcje/ibe-raport-talis-2013.pdf. (otwarty: 30.07.2015).

Poraj G. (2009). Od pasji do frustracji. Modele psychologicznego funkcjonowania nauczycieli. Łódź: Wydawnictwo Uniwersytetu Łódzkiego.

Pyżalski J. (2010). Skutki oddziaływania warunków pracy na polskich nauczycieli. W: Pyżalski J., Merecz D. (red.). Psychospołeczne warunki pracy polskich nauczycieli. Pomiędzy wypaleniem zawodowy a zaangażowaniem. Kraków: Impuls.

Pyżalski J., Plichta P. (2007). Kwestionariusz Obciążeń Zawodowych Pedagoga $(K O Z P)$. Podręcznik. Łódź: Wydawnictwo Uniwersytetu Łódzkiego.

Raport o stanie edukacji 2013. Licza się nauczyciele (2014). Warszawa: IBE, dostępny na: http://entuzjasci.pl/images/stories/publikcje/ibe-raport-o stanie-edukacji-2013.pdf. (otwarty: 30.07.2015).

Sekułowicz M. (2002). Wypalenie zawodowe nauczycieli pracujacych z osobami z niepelnosprawnościa intelektualna. Przyczyny-symptomy-zapobieganie-przezwyciężanie. Wrocław: Wydawnictwo Uniwersytetu Wrocławskiego. 
Sekułowicz M. (2005). Nauczyciele szkolnictwa specjalnego wobec zagrożenia wypaleniem zawodowym: analiza przypadków. Wrocław: Wydawnictwo Naukowe DSWE TWP.

Sęk H. (1996). Wypalenie zawodowe. Psychologiczne mechanizmy i uwarunkowania. Poznań: Zakład Wydawniczy K. Domke.

Sowińska A. (2014). Zadowolenie z pracy - problemy definicyjne. „Studia Ekonomiczne/Uniwersytet Ekonomiczny w Katowicach”, 197: Edukacja w świetle przemian współczesnego rynku pracy: wybrane problemy, s. 45-56.

Springer A. (2011). Wybrane czynniki kształtujace satysfakcję pracownika. „Problemy Zarządzania", t. 9, nr 4 (34), s. 162-180.

Stelmach W. (2005). Ciemne strony planowania. Warszawa: Agencja Wydawnicza Placet.

Terelak J. F., Izwantowska A. (2009). Adaptacja kwestionariusza Obszary Życia Zawodowego (Areas of Worklife Survey) Christiny Maslach i Michaela Leitera. "Studia Psychologica UKSW”, 9, s. 223-232.

Tucholska S. (2009). Wypalenie zawodowe u nauczycieli. Psychologiczna analiza zjawiska i jego osobowościowych uwarunkowań. Lublin: KUL.

Wnuk M., Zielonka D., Purandare B., Kaniewski A., Klimberg A., Ulatowska-Szostak E., Palicka E., Zarzycki A., Kaminiarz E. (2013). Przegląd koncepcji jakości życia w naukach społecznych. „Hygeia Public Health”, 48 (1), s. 10-16, dostępny na: http://www.h-ph.pl/pdf/hyg-2013/hyg-2013-1-o10.pdf (otwarty: 30.07.2015).

Wołowska A. (2013). Satysfakcja z pracy i jej wyznaczniki a poczucie jakości życia urzędników. „Rocznik Andragogiczny”, nr 20, s. 119-132.

Wudarzewski G. (2013). Satysfakcja z pracy - konceptualizacja pojęcia $w$ świetle badań literaturowych. „Zeszyty Naukowe Wyższej Szkoły Bankowej we Wrocławiu", nr 5 (37), s. 323-344.

Zalewska A. (2001). „Arkusz Opisu Pracy” O. Neubergera i M. Allerbeck-adaptacja do warunków polskich. „Studia Psychologiczne”, t. 39, nr 1, s. 197-217.

Zalewska A. (2009). Wiek, płeć i stanowisko pracy a zadowolenie ż̇ycia. „Psychologia Jakości Życia”, t. 8, nr 1, s. 1-20.

\section{PROFESSIONAL CONDITIONS OF WORK SATISFACTION AMONGST TEACHERS}

Abstract: Work is a basic form of human activity, and job satisfaction becomes a source
of life satisfaction. This is particularly essential in the case of teachers. Studies prove that
the higher the job satisfaction of teachers is, the lower the rates of burnout. The article pre-
sents the issue of professional determinants of job satisfaction derived by male and female
teachers in the three stages of professional experience: professional adaptation - 1-5 years
of practice; professional stabilisation - 6-20 years of practice; expert stage - 21-35 years of 
professional activity. It has been researched whether gender and job seniority determine the level of job and life satisfaction gained by the surveyed teachers. Additionally, the correlation between job and life satisfaction of male and female teachers in the specified periods of seniority has been presented.

Keywords: job satisfaction, life satisfaction, burnout.

Elżbieta Lisowska - doktor, starszy wykładowca w Instytucie Pedagogiki i Psychologii Wydziału Pedagogicznego i Artystycznego Uniwersytetu Jana Kochanowskiego w Kielcach. Autorka publikacji: Diagnostyka pedagogiczna w pracy $z$ dzieckiem i rodzina (Kielce 2008), Rozpoznawanie i przewidywanie wypalenia zawodowego nauczycieli. Studium pedagogiczne (Kielce 2012). Adres do korespondencji: ul. Krakowska 11, 25-029 Kielce. Adres e-mailowy: elzbieta.lisowska@ujk.edu.pl. 